\title{
Ballpoint Pen Technique
}

National Cancer Institute

\section{Source}

National Cancer Institute. Ballpoint Pen Technique. NCI Thesaurus. Code C150875.

A technique used to measure the skin induration diameter of intradermal tuberculin tests based on resistance to the movement of a ballpoint pen across the skin. 